\title{
Prediction of Self-Compacting Rubberized Concrete Mechanical and Fresh Properties using Taguchi Method
}

\author{
Emara MA*, Eid FM, Nasser AA and Safaan MA
}

Faculty of Engineering, Department of Civil Engineering, Menoufia University, Egypt

\begin{abstract}
The effect and optimization of using self-compacting rubberized concrete was investigated by using Taguchi method. Design of experiment was performed via orthogonal array to accommodate four factors with four levels. These factors were the percentage of fine rubber, coarse rubber, fly ash and viscocrete in the concrete mix. The signal-to-noise $(\mathrm{S} / \mathrm{N})$ ratio and the analysis of variance (ANOVA) were employed to study the performance characteristics of self-compacting rubberized concrete (SCRC). Rubberized concrete can be improved using the concrete proportioned as self-compacting concrete. The results indicate that there was a reduction in the strength with increasing rubber content but there was an increase in impact resistance. However, the replacement of $10 \%$ of coarse aggregate with coarse rubber gave more strength than that of zero rubber mix by $124 \%$ at 90 days. Replacement of $20 \%$ of both fine and coarse aggregates with fine and coarse rubber respectively, increased impact resistance by $453 \%$ compared to the corresponding SCRC control mix.
\end{abstract}

Keywords: Rubber; Recycling; Self-compacting; Taguchi method; ANOVA

\section{Introduction}

Self-Compacting Concrete (SCC) is a sophisticated highperformance concrete [1] described as the "most revolutionary step" in concrete technology over the last two decades due to its impact on economic and environmental sustainability in the construction industry [2]. It offers the advantages of increased productivity rates, decreased manpower, and elimination of the noise and fuel consumption associated with vibrator plant [3]. In comparison with plain concrete, it has the ability to fully self-compact under its own weight and has high flow ability and filling rates, reduced blocking in congested reinforced areas, and high segregation resistance, as well as high durability, low permeability and high compressive strength [4].

Solid waste disposal is a major environmental issue on cities around the world [5]. The volume of polymeric waste like tire rubber is increasing. The waste tires rubber becomes an environmental problem due to its non-biodegradable nature. Up to now a small part is recycled and millions of tires are just stockpiled; land filled or buried and used as fuel in many industries. Recycling end-of-life vehicle tires as alternative aggregates to produce a new class concrete is an innovative option with environmental, economic and performance benefits [5].

Many researchers have therefore used rubber particles as aggregates in concrete production to eliminate poor deformation capacity, low tensile strength, and improve energy absorption capacity. Aggregate rubber particles enhanced deformation and energy absorption capacities while they decreased workability and mechanical properties [6]. Selfcompacting rubberized concrete (SCRC) was produced to diminish the negative effect of rubber aggregate on the mechanical properties and workability of concrete [7]. Due to the high powder content of SCC its microstructure is very compacted and dense, which results in high mechanical strength and brittle failure modes. Therefore, (SCRC) composites could be used for applications requiring deformable (high ductility concrete with high flowability and low/medium strength ( $<35 \mathrm{MPa}$ ), which is difficult to achieve using SCC using alternative aggregates that are environmentally friendly (sustainable concrete). In infrastructure applications the range of strength is usually between 28 and $35 \mathrm{MPa}$. In applications such as bridge barriers and road foundations, concrete with high deformation and high toughness is desirable while $>35 \mathrm{MPa}$ compressive strength is not required $[5,8]$.

\section{Aim of Work}

In the current research fresh and harden properties of (SCRC) were investigated using Taguchi method. Sixteen different concrete mixes were designed with the same water/powder ratio $\mathrm{W} / \mathrm{P}(\mathrm{P}=$ cement+fly ash). Their self-compacting characteristics and final mechanical behavior are reported and discussed.

\section{Parameter Design Methodology}

Taguchi's parameter design method is a powerful tool for optimizing the characteristic performance of a product/process. Optimization quality characteristic minimizes Sensitivity to Noise (S/N) (uncontrollable) factors. In the present study, four control factors were chosen with four levels as shown in Table 1.

\section{Design of experiment}

The experiment was designed based on the orthogonal array technique. An orthogonal array is a fractional factorial design. It is obtained by assigning the selected factors and their levels to appropriate columns of L16 orthogonal array. This array has 16 rows and 4 columns, each row represents a trial condition and each column accommodates a specific process parameter. The main effects can be estimated. The numbers in each column indicate the levels of specific factors $(A, B, C$ and D). Taguchi Orthogonal Array Design is L16 $\left(4^{\star *} 4\right)$. Factors are 4. Runs are 16 [9-11].

\section{Taguchi's orthogonal array approach of experimental design}

Taguchi's target is developing products that achieve the target value on a consistent basis. The variation around the target value should be minimized. In other words, quality is achieved by minimizing the

*Corresponding author: Emara MA, Faculty of Engineering, Department of Civil Engineering, Menoufia University, Gamal Abdul-Nasser Street, Menoufia University, Egypt, Tel: +20 48 2222170; E-mail: mohamedhakeememara@gmail.com

Received October 14, 2017; Accepted February 19, 2018; Published February 23, 2018

Citation: Emara MA, Eid FM, Nasser AA, Safaan MA (2018) Prediction of SelfCompacting Rubberized Concrete Mechanical and Fresh Properties using Taguchi Method. J Civil Environ Eng 8: 301. doi: 10.4172/2165-784X.1000301

Copyright: @ 2018 Emara MA, et al. This is an open-access article distributed under the terms of the Creative Commons Attribution License, which permits unrestricted use, distribution, and reproduction in any medium, provided the original author and source are credited. 
Citation: Emara MA, Eid FM, Nasser AA, Safaan MA (2018) Prediction of Self-Compacting Rubberized Concrete Mechanical and Fresh Properties using Taguchi Method. J Civil Environ Eng 8: 301. doi: 10.4172/2165-784X.1000301

Page 2 of 8

\begin{tabular}{|c|c|c|c|}
\hline \multirow{2}{*}{ Level } & \multicolumn{3}{|c|}{ Factors } \\
\cline { 2 - 4 } & Replacement of fine aggregates by fine rubber & Replacement of coarse aggregates by coarse rubber & Fly-ash (cement \%) \\
\hline & $0 \%$ & $0 \%$ & $20 \%$ \\
\hline 2 & $10 \%$ & $10 \%$ & $25 \%$ \\
\hline 3 & $15 \%$ & $15 \%$ & $2.00 \%$ \\
\hline 4 & $20 \%$ & $20 \%$ & $30 \%$ \\
\hline
\end{tabular}

Table 1: Control factors of the experimental work.

\begin{tabular}{|c|c|c|c|c|}
\hline \multirow{3}{*}{ Exp. No. } & \multicolumn{4}{|c|}{ Factors } \\
\hline & \multicolumn{2}{|c|}{$\%$ Replacement by volume of aggregate } & \multicolumn{2}{|c|}{ Addition (\% wt of cement) } \\
\hline & Fine rubber & Coarse rubber & Fly ash & viscocrete \\
\hline 1 & 0 & 0 & 20 & 2 \\
\hline 2 & 0 & 10 & 25 & 2.25 \\
\hline 3 & 0 & 15 & 30 & 2.5 \\
\hline 4 & 0 & 20 & 35 & 2.75 \\
\hline 5 & 10 & 0 & 25 & 2.5 \\
\hline 6 & 10 & 10 & 20 & 2.75 \\
\hline 7 & 10 & 15 & 35 & 2 \\
\hline 8 & 10 & 20 & 30 & 2.25 \\
\hline 9 & 15 & 0 & 30 & 2.75 \\
\hline 10 & 15 & 10 & 35 & 2.5 \\
\hline 11 & 15 & 15 & 20 & 2.25 \\
\hline 12 & 15 & 20 & 25 & 2 \\
\hline 13 & 20 & 0 & 35 & 2.25 \\
\hline 14 & 20 & 10 & 30 & 2 \\
\hline 15 & 20 & 15 & 25 & 2.75 \\
\hline 16 & 20 & 20 & 20 & 2.5 \\
\hline
\end{tabular}

Table 2: Experimental test design of control factors with factor levels.

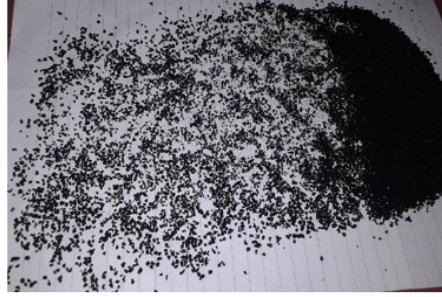

a) Fine rubber $(2 \mathrm{~mm})$

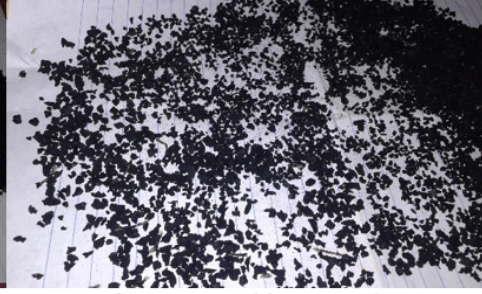

b) Coarse rubber $(5 \mathrm{~mm})$

Figure 1: Fine and coarse rubber.

deviation from the target. Factors and levels are illustrated in Table 1; the mixes are given in Table 2. Factor A is replacement of fine aggregate by fine rubber $(1 \mathrm{~mm})$ (replaced by $0 \%, 10 \%, 15 \%$ and $20 \%)$. Factor B is replacement of coarse aggregate by coarse rubber $(5 \mathrm{~mm})$ (replaced by $0 \%, 10 \%, 15 \%$ and $20 \%$ ). Factor $\mathrm{C}$ is addition of fly ash as a ratio of cement (added by 20,25,30, and 35\%). Factor D is using superplasticizer (viscocrete) as a ratio of cement $(2.00 \%, 2.25 \%, 2.50 \%$ and $2.75 \%)[11,12]$.

\section{Materials and Methods}

\section{Materials}

All test specimens were fabricated using locally available materials.

Cement: A locally produced ordinary Portland cement (42.5 $\mathrm{N})$ produced by Lafarge Company meeting the requirement of E.S. $373 / 2003$ was used with constant content $\left(400 \mathrm{~kg} / \mathrm{m}^{3}\right)$ for all mixes.

Fly ash: Sika fly ash type P from Sika Egypt Company (El Obour factory) was used as addition to cement.
Fine aggregate: The sand used was local natural siliceous sand with fineness modulus 2.77 and specific gravity 2.64 .

Coarse aggregate: Coarse aggregate used was natural crushed limestone with maximum aggregate size of $12 \mathrm{~mm}$ to achieve the requirement of self-compacting concrete.

Super plasticizer: A high range water reducer without retarding was used. (Sika viscocrete 3425) was used as a demand for producing SCC. It meets the requirements for superplasticizers according to ASTM-C- 494 Types G and F and BS EN 934 part 2: 2001.

Fine rubber aggregate: The fine crumb rubber used in this research is produced by MARSO factory at $10^{\text {th }}$ Ramadan city-Egypt with size of $(1 \mathrm{~mm})$ and was used as a partial replacement (by volume) of fine aggregate (Figure 1).

Coarse rubber aggregate: The coarse rubber used in this research is produced by MARSO factory at $10^{\text {th }}$ of Ramadan city-Egypt with one size of ( $5 \mathrm{mms}$ ) and was used as a partial replacement (by volume) of coarse aggregate (Figure 1). 


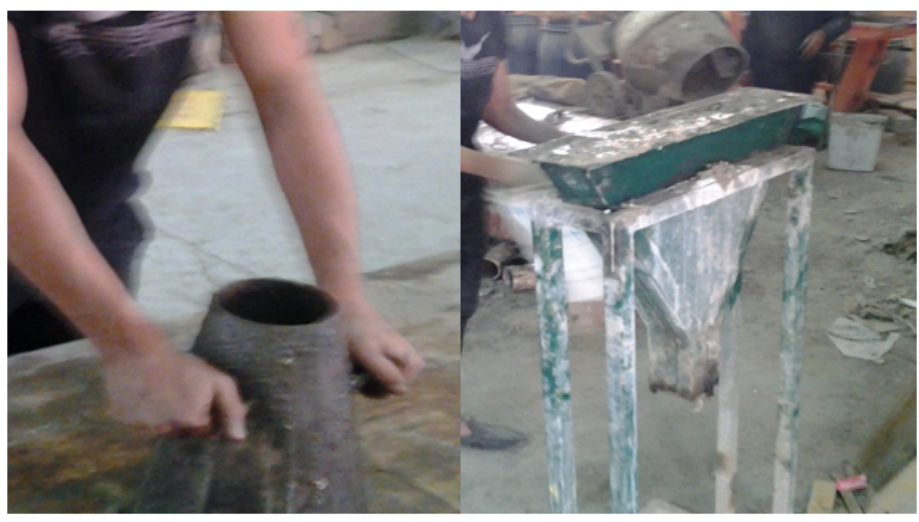

Slump flow test

V-Funnel test

Figure 2: Fresh tests.

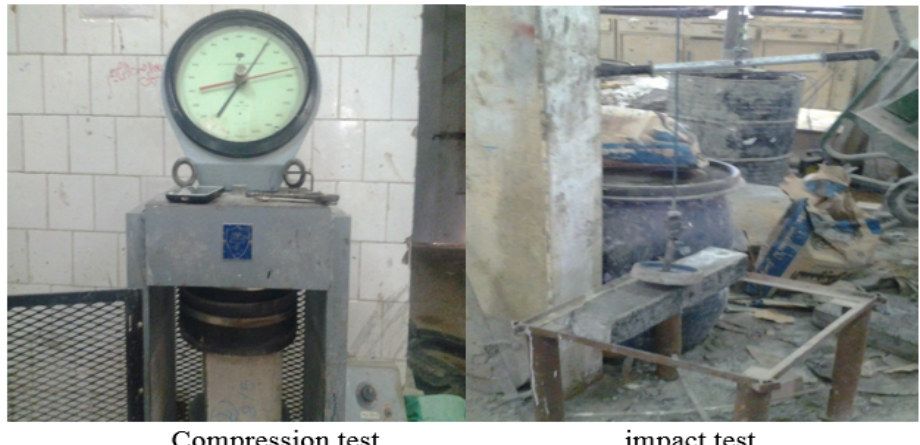

Compression test

impact test

Figure 3: Hardened tests.

Water: Fresh tap water was used with water /binder ratio $\mathrm{w} / \mathrm{b}=0.37$.

\section{Mix contents and procedure}

Mix contents: The cement content was constant at $400 \mathrm{~kg} / \mathrm{m}^{3}$ for all mixes with water/binder ${ }^{*}$ ratio of 0.37 and the mix proportion ratio (of weight) for cement: sand: dolomite was 1:2.125:2.125 respectively.

*binder=cement + fly ash

Mixing procedure: It was carried out in three stages; dry mix for 2 min, adding $75 \%$ of (water+S.P) and mixing for $2 \mathrm{~min}$ and a final mix for not less than 3 min after adding the remaining amount of (water+S.P). Subsequently, the fresh properties of SCRC mixes; Flowability and Passing-ability tests (slump flow, T50, V-Funnel and J-Ring) were determined. Concrete specimens were cast in standard steel molds. After $24 \mathrm{~h}$ from mixing, all the specimens were de-molded and cured in wet canvas for 7 days.

\section{Tests}

Fresh tests: Fresh tests were performed according to the procedure recommended by EFNARC committee (European Federation for Specialist Construction Chemicals and Concrete Systems) [13]. (Figure 2).

Slump flow test: Slump flow value describes the flowability of a fresh mix in unconfined conditions. It is a sensitive test that can normally be specified for all self-compacting concretes, as the primary check that the fresh concrete consistence meets the specification [8] (Figure 2).

$V$-funnel: When performing the V-funnel test, a V shaped funnel is filled with fresh concrete and the time taken for the concrete to flow out of the funnel is measured and recorded as the V-funnel flow time (Figure 2).

\section{Hardened SCRC}

Compressive strength test: Test was carried out on $15 \times 15 \times 15 \mathrm{~cm}$ cubes and according to ASTM C39-86. The capacity of the compression machine used is $2000 \mathrm{KN}$.

Impact test: Beams $10 \mathrm{~cm} \times 10 \mathrm{~cm} \times 50 \mathrm{~cm}$ were prepared for this test. The impact resistance was assessed by measuring the ability of concrete specimens to withstand repeated blows of a free failing load $(3 \mathrm{~kg})$ at a constant travelling height of $40 \mathrm{~cm}$ above the midpoint of the tested concrete beam which was supported on two ends. The load was then left to fall freely on the top side of the concrete beam and the number of impact blows to cause failure was recorded [14-16]. Figure 3 shows the hardened tests set up.

\section{Results}

\section{Fresh properties}

Experimental test results of fresh properties for slump flow and V-Funnel tests for SCRC are shown in Table 3.

\section{Hardened properties}

Experimental test results of compressive strength for SCRC are shown in Table 4 . Table 5 shows test results for impact resistance which represented by numbers of blows. 
Citation: Emara MA, Eid FM, Nasser AA, Safaan MA (2018) Prediction of Self-Compacting Rubberized Concrete Mechanical and Fresh Properties using Taguchi Method. J Civil Environ Eng 8: 301. doi: 10.4172/2165-784X.1000301

Page 4 of 8

\begin{tabular}{|c|c|c|c|c|c|}
\hline Mix. No. & Slump (mm) & V-funnel(sec.) & Mix. No. & Slump (mm) & V-funnel (sec.) \\
\hline 1 & 723 & 3.65 & 9 & 675 & 13.94 \\
\hline 2 & 735 & 3.79 & 10 & 690 & 7.2 \\
\hline 3 & 755 & 3.56 & 11 & 550 & 18.25 \\
\hline 4 & 720 & 6.47 & 12 & 585 & 14.97 \\
\hline 5 & 710 & 7.81 & 13 & 665 & 6.16 \\
\hline 6 & 740 & 5.89 & 14 & 630 & 11.03 \\
\hline 7 & 715 & 6.71 & 15 & 605 & 17.53 \\
\hline 8 & 645 & 5.72 & 16 & 560 & 9.22 \\
\hline
\end{tabular}

Table 3: Experimental test results (fresh properties).

\begin{tabular}{|c|c|c|c|c|c|c|c|}
\hline \multirow{2}{*}{ Mix. No. } & \multicolumn{3}{|c|}{ Compressive strength (Mpa) } & \multirow{2}{*}{ Mix. No. } & \multicolumn{3}{|c|}{ Compressive strength (Mpa) } \\
\hline & 7 days & 28 days & 90 days & & 7 days & 28 days & 90 days \\
\hline 1 & 33.2 & 47.7 & 52 & 9 & 22.1 & 31.6 & 44.5 \\
\hline 2 & 40.3 & 53.3 & 64.4 & 10 & 21.3 & 32.9 & 37.3 \\
\hline 3 & 27.6 & 37.7 & 44.4 & 11 & 20.4 & 24.8 & 32.2 \\
\hline 4 & 21.6 & 347 & 456 & 12 & 19 & 24.3 & 29 \\
\hline 5 & 28.4 & 421 & 483 & 13 & 23 & 38.4 & 32.2 \\
\hline 6 & 23.9 & 35.8 & 43.9 & 14 & 23.9 & 25.7 & 33.6 \\
\hline 7 & 21.9 & 33.2 & 41.2 & 15 & 20.8 & 24.8 & 30.2 \\
\hline 8 & 20.2 & 26 & 38.3 & 16 & 18.3 & 20.2 & 29.8 \\
\hline
\end{tabular}

Table 4: Compressive strength test results (hardened properties).

\begin{tabular}{|c|c|c|c|}
\hline \multirow{2}{*}{ Mix. No. } & Impact (blows) & \multirow{2}{*}{ Mix. No. } & \multirow{2}{*}{$\begin{array}{c}\text { Impact (blows) } \\
28 \text { days }\end{array}$} \\
\hline & 28 days & & \\
\hline 1 & 17 & 9 & 23 \\
\hline 2 & 13 & 10 & 21 \\
\hline 3 & 15 & 11 & 31 \\
\hline 4 & 15 & 12 & 31 \\
\hline 5 & 29 & 13 & 35 \\
\hline 6 & 23 & 14 & 54 \\
\hline 7 & 22 & 15 & 55 \\
\hline 8 & 22 & 16 & 77 \\
\hline
\end{tabular}

Table 5: Impact test results.

\section{Analysis and Discussion}

Design of experiment data is used to analyze the mean response function. In Taguchi technique, the variation of the response is examined using an appropriately chosen $\mathrm{S} / \mathrm{N}$ ratio. This ratio is the mean (signal) to the standard deviation (noise). The ratios, derived from the quadratic loss function, are expressed on a decibel (dB) scale. The formula used to compute the $\mathrm{S} / \mathrm{N}$ ratio depends on the objective function. Generally, three standard $\mathrm{S} / \mathrm{N}$ equations are widely used to classify the objective function as: 'larger the better', 'smaller the better', or 'nominal the best'. Focusing on the strength characteristic, a larger $\mathrm{S} / \mathrm{N}$ ratio is always desirable.

In the present study, compressive and impact resistance are larger is better' types of quality characteristic since the goal is to maximize the strength. The standard $\mathrm{S} / \mathrm{N}$ ratio computing formula for this type of response is:

$$
\left(\frac{S}{N}\right)_{i}=-10 \log \left[\frac{1}{n} \sum_{j=1}^{n} \frac{1}{Y_{i j}^{2}}\right]
$$

V-funnel is a 'smaller is better' type of quality characteristic since the goal is to minimize them. The standard $\mathrm{S} / \mathrm{N}$ ratio computing formula for this type of response is:

$$
\left(\frac{S}{N}\right)_{i}=-10 \log \left[\frac{1}{n} \sum_{j=1}^{n} Y^{2}\right]
$$

Where ' $\mathrm{i}$ ' is the number of a trial; 'Yij' is the measured value of quality characteristic for the ith trial and jth experiment; ' $n$ ' is the number of repetitions for the experimental combination. Signal-tonoise ratios are computed using Equation (1) for each experimental condition for compressive and impact resistance. The factor effects can be separated out in terms of $\mathrm{S} / \mathrm{N}$ ratio.

The analysis of variance (ANOVA) is also performed to study the relative significance of the process parameters. The contributions of the various parameters are quantified.

\section{Fresh properties}

The filling ability and stability of SCRC in the fresh state can be defined by four key characteristics namely flow ability, viscosity, passing ability, and segregation resistance. Each characteristic can be addressed by one or more test methods [13]. For instance, flow ability can be measured via slump flow test, viscosity can be measured through the $\mathrm{V}$-funnel flow time tests.

Self-compacting concrete requirements in the fresh state that are appropriate for a given application should be selected from one or more of above mentioned four key characteristics and then specified by class or target value. To define the flow ability, viscosity, passing ability, and segregation resistance of the produced SCRC, slump flow diameter and V-funnel flow time of the all produced concretes were measured and presented.

Slump flow test: The average values of $\mathrm{S} / \mathrm{N}$ ratios of the control 
Citation: Emara MA, Eid FM, Nasser AA, Safaan MA (2018) Prediction of Self-Compacting Rubberized Concrete Mechanical and Fresh Properties using Taguchi Method. J Civil Environ Eng 8: 301. doi: 10.4172/2165-784X.1000301

Page 5 of 8

factors for slump flow test are shown in Table 6 and Figure 4. Table 7 shows the analysis of variance for this test. Increasing rubber content decreased slump flow diameter but increasing fly ash and/or viscocrete increased slump flow diameter. Addition fly ash to the mix increased cement paste volume which made the mix more flowability. Viscocrete increased the viscosity of concrete which increased the slump flow diameter.

V-Funnel test: As mentioned above, V-Funnel test is measuring the viscosity like T50 test. But here, viscocrete has $2^{\text {nd }}$ rank in $\mathrm{S} / \mathrm{N}$ analysis which mean that it has a big effect on V-Funnel test. However, using the highest content of viscocrete $(2.75 \%)$ increased the time of this test as shown in Figure 5. like T50, increasing rubber content increased V-Funnel time. The average values of $\mathrm{S} / \mathrm{N}$ ratios of the control factors for this test are shown in Table 8 and Figure 5. Table 9 shows the analysis of variance for this test.

\section{Hardened properties}

The mean of three tested values at 28 days was recorded to determine the compressive and impact resistance for all mixtures.

Compressive strength: It was found that increasing rubber content decreased the compressive strength. The deterioration in compressive strength can logically be attributed to (i) the low modulus of elasticity (E) for rubber particles and high Poisson ratio (v) which may encourage premature cracking under load, (ii) increased porosity due to air entrainment from rubber particles, and (iii) weak bonding in the interfacial transition zone between the cement paste and rubber particles which could be due to crack initiation from the voids that form between crumb rubber particles and cement paste. Therefore, under compression loading the aggregates can be susceptible to pullout resulting in particle perimeter voids and crack initiation sites. For fly ash, increasing fly ash content increased compressive strength as it works as a filler which fills the voids on concrete. Using $35 \%$ of fly ash as addition to the mix gave highest compressive strength. Viscocrete has small effect on compressive strength. It had the $4^{\text {th }}$ rank in $\mathrm{S} / \mathrm{N}$ analysis. But the addition of super plasticizer in (SCC) gives more strength in early age. The average values of $\mathrm{S} / \mathrm{N}$ ratios of the control factors for compressive strength test are shown in Table 10 and Figure 6. Table 11 shows the analysis of variance for this test.

Impact resistance: Increasing rubber content led to increase impact resistance. The impact resistance, as a number of blows, increased from 17 blows for mix No.1 (no rubber replacement) to 77 blows for mix No.16 (20\% fine rubber and 20\% coarse rubber). This gain of impact resistance of SCRC is due to the ability of rubber

\begin{tabular}{|c|c|c|c|c|}
\hline Level & Fine rubber (A) & Coarse rubber (B) & Fly ash (C) \\
\hline 1 & 57.3 & 56.81 & 56.08 \\
\hline 2 & 56.92 & 56.87 & 56.33 \\
\hline 3 & 55.88 & 56.27 & 56.4 \\
\hline 4 & 55.76 & 55.91 & 56.2 \\
\hline Delta & 1.54 & 0.96 & 56.87 \\
\hline Rank & 1 & 2 & 56.69 \\
\hline
\end{tabular}

Table 6: Response of signal to noise ratios for slump flow (larger is better).

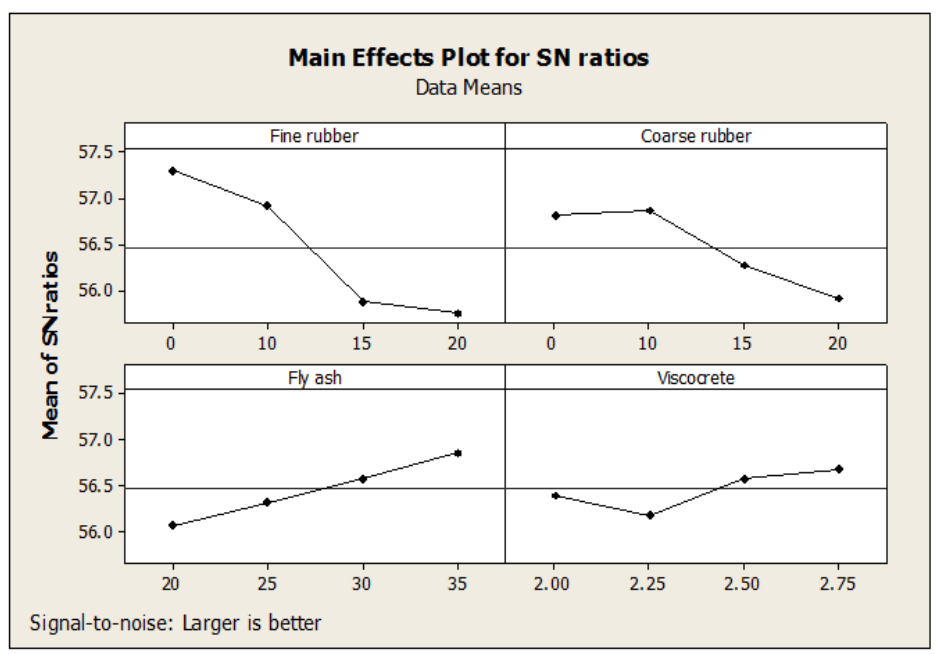

Figure 4: Main effect plot for signal to noise ratio of slump flow (larger is better)

\begin{tabular}{|c|c|c|c|c|}
\hline Source & DF & Seq SS & Adj SS & Adj MS \\
\hline Fine rubber & 3 & 40345 & 40345 & 13448.3 \\
\hline Coarse rubber & 3 & 13407 & 13407 & 4469.1 \\
\hline Fly ash & 3 & 6557.4 & 6557.4 & 2185.8 \\
\hline Viscocrete & 3 & 3182.4 & 3182.4 & 1060.8 \\
\hline Error & 3 & 2344.9 & 2344.9 & 7.97 \\
\hline Total & 15 & 65837 & - & -9.96 \\
\hline
\end{tabular}

Table 7: Analysis of Variance for slump flow test, using adjusted SS for tests. 
Citation: Emara MA, Eid FM, Nasser AA, Safaan MA (2018) Prediction of Self-Compacting Rubberized Concrete Mechanical and Fresh Properties using Taguchi Method. J Civil Environ Eng 8: 301. doi: 10.4172/2165-784X.1000301

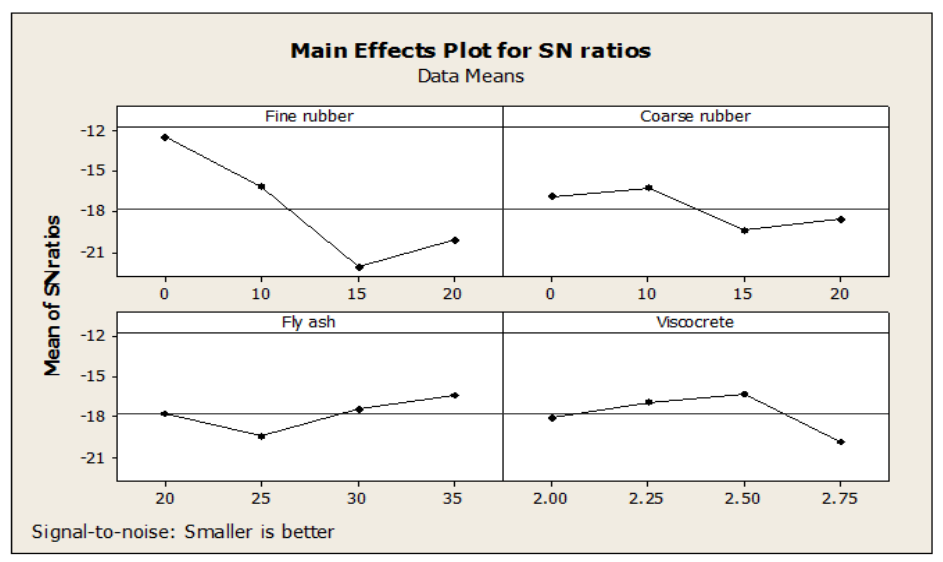

Figure 5: Main effect plot for signal to noise ratio of $\mathrm{V}$-funnel results (smaller is better).

\begin{tabular}{|c|c|c|c|c|}
\hline Level & Fine rubber (A) & Coarse rubber (B) & Fly ash (C) & -17.79 \\
\hline 1 & -12.52 & -16.94 & -19.45 \\
\hline 2 & -16.23 & -16.24 & -18.03 & -16.93 \\
\hline 3 & -22.19 & -19.42 & -16 \\
\hline 4 & -20.2 & -18.54 & -16.42 & 3.03 \\
\hline Delta & 9.67 & 3.17 & -19.85 \\
\hline
\end{tabular}

Table 8: Response of signal to noise ratios for V-funnel (smaller is better).

\begin{tabular}{|c|c|c|c|c|}
\hline Source & DF & Seq SS & Adj SS & Adj MS \\
\hline Fine rubber & 3 & 209.95 & 209.95 & 69.984 \\
\hline Coarse rubber & 3 & 46.302 & 46.302 & 15.434 \\
\hline Fly ash & 3 & 39.52 & 39.52 & 13.173 \\
\hline Viscocrete & 3 & 33.017 & 33.017 & 11.006 \\
\hline Error & 3 & 23.628 & 23.628 & 7.87 \\
\hline Total & 15 & 352.42 & - & - \\
\hline
\end{tabular}

Table 9: Analysis of variance for V-funnel test, using adjusted SS for tests.

\begin{tabular}{|c|c|c|c|c|}
\hline Level & Fine rubber (A) & Coarse rubber (B) & Fly ash (C) & 49.66 \\
\hline 1 & 52.62 & 51.93 & 50.65 \\
\hline 2 & 50.57 & 51.04 & 49.98 \\
\hline 3 & 48.98 & 49.43 & 50.6 \\
\hline Delta & 48.46 & 48.23 & 50.12 \\
\hline Rank & 4.15 & 3.7 & 49.94 \\
\hline
\end{tabular}

Table 10: Response of signal to noise ratios for compressive strength of 28 days (larger is better).

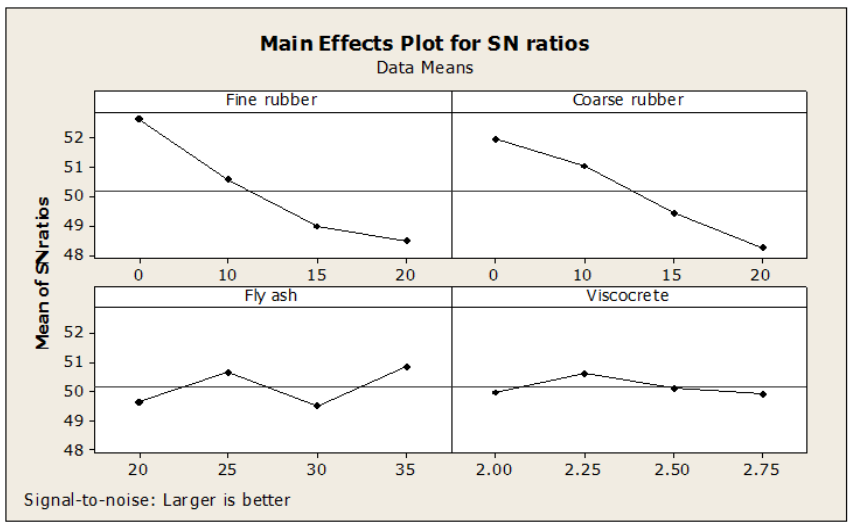

Figure 6: Main effect plot for signal to noise ratio of compressive strength after 28 days (larger is better). 
Citation: Emara MA, Eid FM, Nasser AA, Safaan MA (2018) Prediction of Self-Compacting Rubberized Concrete Mechanical and Fresh Properties using Taguchi Method. J Civil Environ Eng 8: 301. doi: 10.4172/2165-784X.1000301

Page 7 of 8

\begin{tabular}{|c|c|c|c|c|}
\hline Source & DF & Seq SS & Adj SS & Adj MS \\
\hline Fine rubber & 3 & 65266 & 65266 & 21755 \\
\hline Coarse rubber & 3 & 46506 & 46506 & 15502 \\
\hline Fly ash & 3 & 8413 & 8413 & 2804 \\
\hline Viscocrete & 3 & 3273 & 3273 & 1091 \\
\hline Error & 3 & 1818 & 1818 & 6.71 \\
\hline Total & 15 & 125275 & - & - \\
\hline
\end{tabular}

Table 11: Analysis of variance for 28 days compressive strength, using adjusted SS for tests.

\begin{tabular}{|c|c|c|c|c|}
\hline Level & Fine rubber (A) & Coarse rubber (B) & Fly ash (C) \\
\hline 1 & 23.06 & 27.01 & 29.99 \\
\hline 2 & 28.24 & 28.11 & 28.82 \\
\hline 3 & 28.57 & 28.96 & 27.7 \\
\hline 4 & 34.35 & 30.15 & 28.45 \\
\hline Delta & 11.29 & 3.14 & 26.97 \\
\hline Rank & 1 & 2 & 3.03 \\
\hline
\end{tabular}

Table 12: Response of signal to noise ratios for impact resistance after 28 days (Larger is better).

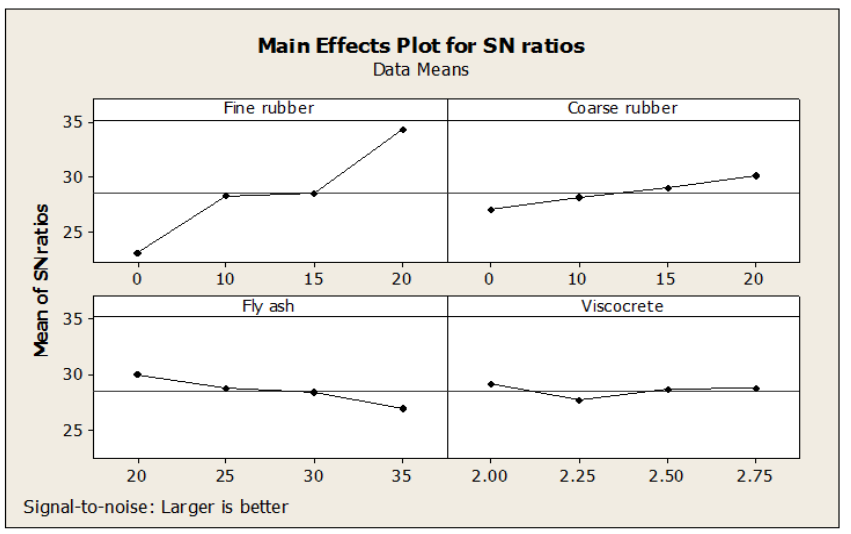

Figure 7: Main effect plot for signal to noise ratio of impact resistance after 28 days (larger is better).

\begin{tabular}{|c|c|c|c|c|}
\hline Source & DF & Seq SS & Adj SS & Adj MS \\
\hline Fine rubber & 3 & 3514.4 & 3514.4 & 1171.45 \\
\hline Coarse rubber & 3 & 467.47 & 467.47 & 155.82 \\
\hline Fly ash & 3 & 443.13 & 443.13 & 14.14 \\
\hline Viscocrete & 3 & 146.41 & 146.41 & 48.8 \\
\hline Error & 3 & 105.24 & 105.24 & 3.47 \\
\hline Total & 15 & 4676.6 & - & -13 \\
\hline
\end{tabular}

Table 13: Analysis of variance for 28 days impact resistance, using adjusted SS for tests.

particles to absorb the plastic energy, which generated from the falling of a mass from a certain height. In addition, the high deflection of the rubberized concrete increases the ability to withstand more energy. Table 12 and Figure 7 shows the average values of $\mathrm{S} / \mathrm{N}$ ratios of the control factors for T50 test. The analysis of variance for this test is shown in Table 13. The percentage of fine rubber replacement was the most significant parameter influencing the impact resistance. The percentage contribution was $75.14 \%$.

\section{Prediction of Optimum Quality Characteristic}

The predicted mean of the quality characteristic for slump flow, V-Funnel, compressive strength and impact resistance is computed using the following equation:

$S_{m p}=\bar{Y}+\left(\bar{A}_{0}-\bar{Y}\right)+\left(\bar{B}_{0}-\bar{Y}\right)+\left(\bar{C}_{0}-\bar{Y}\right)+\left(\bar{D}_{0}-\bar{Y}\right)+\left(\bar{E}_{0}-\bar{Y}\right)$

It is the grand average of performance characteristic.

$$
\left(\bar{A}_{0}-\bar{Y}\right),\left(\bar{B}_{0}-\bar{Y}\right),\left(\bar{C}_{0}-\bar{Y}\right),\left(\bar{D}_{0}-\bar{Y}\right) \text { and }\left(\bar{E}_{0}-\bar{Y}\right)
$$

The following values of factors were chosen: $A=20 \%, B=20 \%$, $\mathrm{C}=35 \%, \mathrm{D}=2.75 \%$

From the analysis of $\mathrm{S} / \mathrm{N}$ ratio and the mean response characteristic, the mean values for SCRC have been predicted as shown in Table 14.

A confirmation mix was performed with the selected factors ( $A=20 \%, B=20 \%, C=35 \%, D=2.75 \%)$ and the results were recorded in Table 14. These results were compared with the predicted values, illustrated in Table 14, which obtained from Minitab program. The ratio between the actual values and the predicted values are also illustrated in Table 14 which is in range of $10 \%$ difference so experimental results could be confirmed.

\section{Conclusion}

Taguchi Method was used to predict the mechanical properties of self-compacting rubberized concrete in terms of compressive strength and impact resistance and fresh properties in terms of slump flow 
Citation: Emara MA, Eid FM, Nasser AA, Safaan MA (2018) Prediction of Self-Compacting Rubberized Concrete Mechanical and Fresh Properties using Taguchi Method. J Civil Environ Eng 8: 301. doi: 10.4172/2165-784X.1000301

Page 8 of 8

\begin{tabular}{|c|c|c|c|}
\hline Test & $\begin{array}{c}\text { Experimental results of the } \\
\text { confirmation mix }\end{array}$ & $\begin{array}{c}\text { Taguchi predicted value of predicted value and actual } \\
\text { value }\end{array}$ \\
\hline Slump flow & $645 \mathrm{~mm}$ & $618.28 \mathrm{~mm}$ \\
\hline V-funnel & 10.224 seconds & 11.0663 seconds \\
\hline Compression & $19.34 \mathrm{MPa}$ & $20.1 \mathrm{MPa}$ \\
\hline Impact & 51 blows & 55 blows \\
\hline
\end{tabular}

Table 14: Taguchi predicted values and actual values for SCRC.

diameter and V-Funnel time. The analysis shows that the proposed Taguchi technique was adequate to predict the above properties.

The study also considered examining the influence of different concrete mix proportioning parameters that included fine rubber, coarse rubber, fly ash and viscocrete contents on the studied mechanical and fresh properties.

The analysis of variance using ANOVA shows that the percentage of fine rubber replacement was the most significant parameter influencing the studied mechanical and fresh properties. The percentage contribution was $61.3 \%, 59.6 \%, 52.1 \%$ and $75.14 \%$ for slump flow diameter, V-Funnel, compressive strength and impact resistance respectively.

\section{References}

1. Taha MMR, El-Dieb AS, Abd El-Wahab MA, Abdel-Hameed ME (2008) Mechanical, fracture, and microstructural investigations of rubber concrete. $J$ Mater Civ Eng 20:640-649.

2. Ouchi M, Okamura H (2003) Self-compacting concrete. J Adv Concrete Technol 1: 5-15.

3. Ouchi M, Okamura H (1999) Self-compacting concrete. Development, present use and fucture. First International RILEM stmposuim on Self-compacting Concrete 3-14.

4. Bignozzi MC, Sandrolini $F$ (2006) Tyre rubber waste recycling in self-compacting concrete. Cem Concr Res 36: 735-739.

5. Najim KB, Hall MR (2012) Mechanical and dynamic properties of selfcompacting crumb rubber modified concrete. Constr Build Mater 27:521-530.
6. Mishra M, Panda KC (2015) Influence of rubber on mechanical properties of conventional and self-compacting concrete. Adv Struct Eng 1785-1794.

7. Khalil E, Abd-Elmohsen M, Anwar MA (2015) Impact resistance of rubberized self-compacting concrete. Water Sci 29: 45-53.

8. Güneyisi E (2010) Fresh properties of self-compacting rubberized concrete incorporated with fly ash. Mater Struct 43:1037-1048.

9. Ghazy MF (2012) Effect of using mortar interface and overlays in masonry behavior by using Taguchi method. ACI Mater J 109: 509-516.

10. Ghazy MF, Abd El Hameed MF (2015) Optimization of lightweight concrete process by Gray Taguchi Method. ACI Mater J 112: 365-374.

11. Zahran MA, Nasser AA (2014) Recycling of cement dust for manufacturing cement bricks. The 7th Int Conf for Develop and the Env in the Arab world March. pp. 23-25.

12. Najim KB (2012) Determination and Enhancement of Mechanical and Thermophysical Behavior of Crumb Rubber-modified Structural Concrete. The University of Nottingham, UK.

13. EFNARC (2005) The European Guidelines for self-compacting concrete: Specification, Production and Use.

14. Eid FM (2003) Properties and fields of application of rubberized concrete. Menofiya University, Egypt.

15. Taha MR, El-Dieb A, Abd El-Wahab M (2003) Fracture toughness of concrete incorporating rubber tire particles. International Conference on Performance of Construction Materials- A new era of building, Cairo, Egypt.

16. Najim, KB, Hall MR (2012) Experimental validation of plain/self-compacting rubberized concrete (PRC/ SCRC) mix designs for structural applications. 14 International Conference of Structural Faults-Repair, Edinburgh, Scotland, UK. 